\title{
Ernest Hemingway's A Farewell to Arms: A Critical Study of War and Its Negative Impact from An Ironic Perspective
}

\author{
Muhammad Dera Farhan Al-Fahdawi \\ Dept. of English, College of Education for Humanities, University of Anbar \\ Al-Tameem Street Ramadi, Al Anbar, Baghdad, 55431. E-mail: muhammaddera1977@gmail.com
}

\section{RETRACTED ON DECEMBER 7,2017}

Following a rigorous, carefully concerns and considered review of the article published in Jurnal Pendidikan Humaniora to article entitled "Ernest Hemingway's A Farewell to Arms: A Critical Study of War and Its Negative Impact from An Ironic Perspective" Vol 5, No 3, pp. 140-144, September 2017.

This paper has been found to be in violation of the Jurnal Pendidikan Humaniora Publication principles and has been retracted.

The article contained redundant material, the editor investigated and found that the paper published in International Journal of English Literature and Social Sciences (IJELS), Vol. 2, No. 4 (Jul-August 2017), pp. 111-115, 2017, DOI: 10.24001/ijels.2.4.13, URL: http://ijels.com/detail/ernest-hemingway-sa-farewell-to-arms-a-critical-study-of-war-and-its-negative-impact-from-an-ironic-perspective/ entitled "Ernest Hemingway's A Farewell to Arms: A Critical Study of war and its negative impact From an Ironic Perspective".

The document and its content has been removed from Jurnal Pendidikan Humaniora, and reasonable effort should be made to remove all references to this article.

The irony is widely used in the post-world war fiction. It is very significant to show the mood of dissatisfaction and disillusionment of society which saw the disaster caused by the World War I. The writer, through the use of the method of irony, brought both the discrepancy between the ideal and reality. The First World War was projected as a golden opportunity foryouths to achieve glory and process. The Americans, after removing the illusioned idealization of wancondemhed the war for its inhuman violence and irrational deaths In order to express this disillusionment and despair, many writers opted for the use of irony Fhey adopted an ironic method to reflect their vision of the life after World War I. A Farewell to Arms fisplays a remarkable use of irony.
Ernest Hemingway, through the use Irony, expresses his disillusionment and disenchantment with the war. He has bitterly denounced war and attacked the romantic notions associated with it and has revealed the misery and horror of it. A Farewell to Arms was published in 1929 after the First World War. Hemingyay suffered the traunatic shock of the First World War like his countrymen. War jolted him entirely and this resulted in a change in his outlook on life. With althis hopes shattered, Hemingway saw "a world f corrupt civilization, decadent institutions, victimized human beings, and a universal meaninglessness and purposelessness of modern existence (Chandel, 1994)." War severely affected the sensitivity of Hemingway. Disillusioned and depressed, he ventured to unmask the ugly face of war. 
Hemingway's novel A Farewell to Arms is based on Hemingway's own experience as a participant in World War I. This novel remarkably reflects his attitudes towards war. In this novel, Hemingway shows the world of war with all its ugliness, violence, insanity, and irrationality. Besides giving an accurate account of the war, Hemingway has given an insightful description of the psychology of the soldiers. Being tired of war and its irrational pogrom, the soldiers started to look for peace. Hemingway got himself recruited as an ambulance driver in the Italian army. He joined the army not because of any dire need or pressure but because of his own romantic notions about war. In his book The Critical Reception of Ernest Hemingway, Ryan (1980) mentioned the views of ambulance drivers who developed the "spectatorial attitudes" towards the war in the First World War. According to him, these ambulance drivers became "watchers of war" because they were not combating but only traveling. Hemingway opted for war for satisfying his restless, adventurous spirit but he was horrified by he saw on the battlefield and returned with permanent wounds on his body and his memory

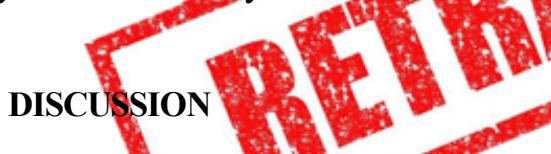

Hemingway's experience with war changes his outlook on life completely. He was wery enthusiastic before being enlisted for war but he was highly depressed and pessimistic when he returned from the war. He was seriously wounded in 1918 at the Italian front when a large number of Austrian mortar shell fell nearly. One of his comrades died instantaneously and another one lost his legs. Hemingway lost consciousness as a result of the shock. After regaining his consciousness, he tried to rescue one of his injured comrades by carrying him to a nearby first aid dugout. During this course, he was shot in his leg by a machine gun fire. In his introduction to his book Men at War, Hemingway gives expression to his illusion about war. He says:

"when you go to war as a boy you have a great illusion of immortality. Other people got killed; not you. Then when you are badly wounded the first time you lose that illusion."

In A Farewell to Arms Hemingway has shown that war is the most irrational and yet most destructive of all human activities as it brings only death, despair and destruction. According to Donaldson (1977), A Farewell to Arms "supplies Hemingway's most extended fictional statement of disillusionment".
Hemingway was equipped with one firsthand experience of war. He himself participated in the First World War, witnessed the holocaust caused by it and suffered not only on the physical side but also on the psychological one. Like many Americans in the prewar period, Hemingway took World War I as an adventure and therefore; participated in it with great zeal. He got himself enlisted in the Italian army as an ambulance driver. During the war, he perceived the difference the ideal and the reality of the world of war. The bitter experience of the reality of the war finds its expression in his novel A Farewell to Arms, where he has clearly given vent to his feelings of hatred of war. According to Elshtain (1987), A Farewell to Arms demonstrates the "reflective puncturing of war myths that most powerfully served to defeat the simplistic, hollow heroics characterizing the western world war".

The novel has Frederic Henry as its central character through whom Hemingway has expressed his distllusionment with the war. An American enlisted in the Jtalian Arny Heny goes through the horrifying experience of wart During the war, he falls in love With Gatherine Barkley, a nurse. Observing the irrationality andabsurdity of the war, Henry tries to escape fromitith order to find what he calls 'separate peace' alone with Catherine. He receives the worst blow when Catherine dies in a childbirth leaving Henry alone in the world. Through the plight of Henry, Hemingway has tried to convey that an escape is not always possible in life. Peace can't be achieved in isolation from others. Hemingway advocates for endurance because he feels that life is essentially tragic.

A Farewell to Arms is a novel on the theme of war and is divided into five sections. The theme of war in this novel is woven with the theme of love. War contrasts sharply with the noble emotion of love. In fact, the novel can be called a tragic love story of Henry and Catherine set the First World War. The title of the novel itself highlights the prominent themes of love and war. Henry bids a farewell to the Italian army and deserts it to make a separate peace, away from the world of war. He bids another farewell the hands of his beloved Catherine who dies in the end during a childbirth. Thus "Henry bids farewell to what he hates most and to what he loves most too. (Rao, Rama, P, 1980)".

Hemingway himself has certain illusions regarding the war which crumbled once he himself participated in the war. Cooper (1987) observes that "the movement from enthusiastic belief in the war and its aims to almost complete skepticism toward its ideals 
and rhetoric was common to many soldiers and most writers who served in this war." Hemingway has very successfully tried to trace the impact of the environment of war on the soldiers. In his introduction to the book Men and War, Hemingway (1942) has insisted on learning "about the human heart and human mind in war".

Hemingway resorts to the use of irony in order to highlight the ugliness of war in contrast with the beauty accompanying love. The title of the novel itself carries irony in it. It is an ambiguous title which shows that the protagonist, Fredric Henry, not only bids farewell to the army and its arms and ammunition but also to the arms of his beloved Catherine who dies an ironic and tragic death in the end. Through the employment of irony, Hemingway has revealed the ironic gap between illusion and reality. It is ironic that the soldiers opt for self-inflicted wounds only to avoid being sent to the war front. Hemingway, here, ironically blames the in-human world of war which has terrorized the soldier to this extent.

In A Farewell to Arms, he has displayed his remarkable understanding of both $n$ the world of war, there is no place for moral values and genuine eino-
tions. War overpowers everything and anyone. Eor Henry love is only a "rotten gane" (A Edrewell-to Arms p.27); a game "like a bridgenin which you said things instead of playing cards. Like the bridge, you had to pretend you are playing for money or playing for some slakes. Nobody mentioned what the stakes were. It was alright for me (A Farewell to Arms p.27).

Henry prefers Catherine not because he has any serious commitment to her but because "this was better than going away every evening to the house for officers where the girls climbed all over you and put your cap on backward as a sign of affection between their trips upstairs with brother officers" (A Farewell to Arms p.26). Henry notices that "Catherine is a little crazy" (A Farewell to Arms p.26). Catherine, in fact, has already suffered the personal loss of her fiancé who has already died in the war. Mentally imbalanced and depressed because of the shock, she is aware of Henry's initial feelings for her and knows that it's only a "rotten game" (A Farewell to Arms p.27). But when Henry meets her in the hospital after his injury, he undergoes an inward change and his flirtatious attitude toward her changes into genuine and true love. He reveals his love for Catherine when he says "God knows I hadn't wanted to fall in love with her. I hadn't wanted to fall in love with anyone. But God knows I had ... and all sorts of things went through my head but I felt wonderful" (A Farewell to Arms p. 70).

In his book Hemingway's First War: The Making of $A$ Farewell to Arms, Reynolds highlights the role of war and its relationship, he states that the war impinges more and more upon the two lovers until it finally separates them. The war, which has reversed all normal patterns of behavior, prevents Fredric and Catherine from marriage, for that would mean separation, yet they become separated anyway (Reynolds, 1996a).

Hemingway has ironically attacked the hypocrisy of the army. He exposes this hypocrisy in the behavior of the soldiers. Though keenly aware of the irrationality and dangers of the war, Henry doesn't leave his job. He sticks to his job in spite of the difficulty involved in it. This senseless violence and meaningless deaths of his comrades bewitder him. The idiocy of the war depresses him. Hertealizes that the "business of war seems to befto mutilate, to kill him. It is a man-made machinery world in which success is as futile as defeat (N.C.Klein, 1994).

1. In A Farewell to Arms, everyone is sick of the wat and depression engulfs everyone. Through the priest, Hemingway has shown the place of religion in the war-stricken world. The priest and his God have become the topics for dirty jokes. The officers have ridiculed and mocked the priest publically. "priest today with girls...priest every night five against one" $(A$ Farewell to Arms p.10). People in general, and soldiers in particular, are left with no faith and belief in religion. Through mocking of the priest, Hemingway is ironically hinting at the debasement of religion in the world of war. Religion is ridiculed openly as it doesn't provide any comfort and relief to the horror-stricken people.

The very opening chapter of the novel has ironic overtones. He notices that every object of nature is short-lived and has an end. The same is true of the soldiers:

The trunks of the trees too were dusty and the leaves fell early that year and we saw the troops marching along the road and the dust rising and leaves stirred by the breeze, falling, and soldiers marching and afterward the road bore and white except for the leaves.(A Farewell to Arms. P.7).

Through such an account of nature, Hemingway ironically and indirectly hints at the doom of the soldiers. Just like the leaves, the soldiers will also fall and die and gradually all of them will become part of the dust. War will eventually finish all of them. 
Again through the use of irony Hemingway has displaced the disinte-gration and destructive nature of war. His irony be-comes explicit while describing the soldiers. He says "passing on the road, marched as though they were six months gone with the child" (A Farewell to Arms p.8). It's ironical that these soldiers were not carrying life with them but violence and death. The irony is reinforced through the symbol of rain. Rain, in this world of war, is not introduced as a giver or sustainer of life. Instead, it makes the miserable life of soldiers all the more miserable. The rain in this novel is developed as a symbol of death as Hemingway has ironically established it in the very first chapter of the novel. Here, rain is associated with disease, suffering, and death. With the arrival of winter" rain comes and with coming of rain there will be cholera. But it was checked and in the end, only seven thousand died of it in the army" (A Farewell to Arms p. 8).

The dark irony of the author is quite explicithere. In the world of war, there is no value of hüman life and the death of 'only' seven thousand soldiersis taken as perfectly normal. Themarch of the soldiers in the mud, the formality of the daily inspectiong of the king, the death of the soldiers in the epidenic of eholera, all are ironically added up to reveal the horrors of the war. The description of the broken houses with smashed walls reveals the destruction caused by the war.

Hemingway has been widely and justly appreciated for his realistic account of the Coporetto retreat. The coporetto section of the novel is full of irony through which Hemingway has revealed the fear, anxiety, panic, confusion, and chaos characterizing a war. With the information of the presence of Germans in the Italian Army, the Italian soldiers would fire at anything and anyone without discrimination. In panic and confusion, they lost their sense of reason and became brutal. Henry, stuck in this night marsh retreat, notices their panic and ironically remarks that the Italians now pose more threat than the Germans. Hemingway has ironically brought forth the discrepancy between war rhetoric and the reality of the war.

The irony becomes more compelling when Henry himself deserts the army to escape the irrational death. $\mathrm{He}$ is interrogated by the Italian battle police, as he is charged with deserting the army. Later he is even suspected as a German in the Italian uniform only because he speaks Italian with an accent. After witnessing the tragic death of his comrades, Henry knows that death awaits him also. The absurd behavior of the Italian battle police is ironically condemned by Henry who observes "how their minds worked if they had minds as if they worked. They were all young men and they were serving their country" (A Farewell to Arms p. 162).

The irony is again employed when Henry observes that the "questioners had that beautiful detachment and devotion to stern justice of men dealing in death without being in any danger of it" ( $A$ Farewell to Arms p.162). Thus Henry "loses his false sense of immortality (Garrety, 1976). Its ironic that Henry, who, initially, had fired at the sergeants for running away now he himself runs away from the soldiers firing at him. He opts for a separate peace with Catherine, away from the world of war. But ironically he is able to live with hesufor a very short time because she dies during achild birth:

The' dazed, bedraggled disorganized spirit of the whole retreat (Reynolds, 1996b) takes the worst form when Henry witnesses the killing of all the officers whorare separated from their men by the Italian battle perice. Henry realizes that life is essentially tragic and that whichever way one goes in the end one is trapped. He learns how to value endurance and fortitude after going through the tragic experience of love and war. Gurko (1986) establishes that war eventually "outlasts the lovers".

In this war novel, A Farewell to Arms Henry has presented a devastating picture of war and its absurdities. He has shown how innumerable soldiers lost their lives in inhuman conditions of war. Lack of food supply, improper medical care, and the deadly conditions contribute towards the accelerating the sense of alienation and depression. Gurko (1986) praises Hemingway for his realistic and veritable account of the war. He states that "A Farewell to Arms could almost serve as a manual on trench warfare" By adopting an ironic perspective in treating the theme of war in A Farewell to Arms, Hemingway maintains that there is nothing glamorous or heroic about war and thus exposes the hollowness and futility of war.

\section{CONCLUSION}

To conclude, World War I darkened the vision of Hemingway. To express his hatred for war, he has adopted an ironic perspective to show the fear, agony, and chaos of the war. He has recorded objectively the atrocities committed during the war which killed not only human beings but also human values. 
Hemingway resorts to the use of irony to show the devastating conditions and ugliness of war. The use of such this ironic perspective stresses the contrast between illusion and reality. Even the title of the novel carries an ironic intended meaning in it. Throughout the employment of irony, Hemingway has displayed the disintegrating and destructive nature of war. Despair and disillusionment became common features of Post -World War I novels. This mood of nihilism, despair, and disillusionment has been reflected in the major works of the time.

\section{REFERENCES}

Chandel, S. S. (1994). Violence in Hemingway. Jaipur: Print Wall.

Cooper, S. (1987). The Politics of Ernest Hemingway. Ann Arbor: UMI Research Press.

Donaldson, S. (1977). By Force of Will, The Life, and Art of Ernest Hemingway. New York: The Viking Press.

Elshtain, J. B. (1987). Women and War. Great Britain. Phe
Garrety, M. (1976). Love and War/ : R.H. Mottram, The Spanish Farm Trilogy and Ernest Hemingway A Farewell to Arms. In H. Klein (Ed.), In The First Worl War in Fiction: A Collection of Critical Essays. London: Macmillan.

Gurko, L. (1986). Ernest Hemingway and the Pursuit of Heroism. New York: Crowell.

Hemingway, E. (1942). Men at War. New York: Berkeley Publishing Cooperation.

Klein, N. C. (1994). The Hemingway Arc. Delhi: Pencraft International.

Rao, Rama, P, G. (1980). Ernest Hemingway: A Study in Narrative Technique. New Delhi: Chand@Company Ltd.

Reynolds. (1996a). Hemingway First War: The Making of A Farewell to Arms. Princeton Univ. Press.

Reynolds, M. . (1996b). A Farewell to Arms: Doctors in the House of Love. In S. Donaldson (Ed.), Ernest Hemingway. Cambridge University Press.

F. L. (1980). The Immediate Critical Reception of Ernest Hetmingway. Washington: University Press Harvester Press Ltd. 